\title{
PENGEMBANGAN BUKU AJAR BAHASA INGGRIS BAGI MAHASISWA EKONOMI
}

\author{
Irene Brainnita Oktarin ${ }^{1}$, Maria Edistianda Eka Saputri ${ }^{2}$ \\ ${ }^{1}$ STIE Gentiaras Bandar Lampung ${ }^{2}$ STIE Gentiaras Bandar Lampung \\ ${ }^{1}$ irenebrainnita.ib@gmail.com ${ }^{2}$ mariaedistianda@gmail.com
}

\begin{abstract}
Abstrak: Penelitian ini bertujuan untuk mengembangkan buku ajar bahasa Inggris bagi mahasiswa jurusan ekonomi sesuai dengan kebutuhan mereka. Subjek uji terdiri dari 2 ahli pembelajaran, 2 teman sejawat, dan 30 mahasiswa untuk uji efektivitas penerapan dengan desain pretest dan posttest. Data dikumpulkan melalui angket dan tes, kemudian dianalisis menggunakan teknik descriptif kuantitatif. Hasil penelitian menunjukkan: (1) skor rata-rata uji terhadap draft I oleh ahli isi sebesar 3,67 dan skor rata-rata uji oleh ahli media sebesar 4,41 yang berkualifikasi sangat baik dan dilakukan perbaikan ringan, (2) skor rata-rata uji terhadap draft II oleh 2 teman sejawat dosen sebesar 4,65 berkualifikasi sangat baik dan dilakukan perbaikan ringan, (3) uji efektifitas penerapan dengan uji t terhadap hasil pretest dan post-test menunjukkan nilai signifikan $(0,00)$ kurang dari 0.05, yang berarti $H_{a}$ diterima, sehingga dapat dikatakan rata-rata hasil posttest lebih baik dibandingkan rata-rata hasil pretest secara signifikan. Dengan demikian, buku ajar bahasa Inggris bagi mahasiswa ekonomi dapat dinyatakan layak untuk diproduksi dan diterapkan.
\end{abstract}

Kata kunci: buku ajar, bahasa Inggris, mahasiswa ekonomi

\begin{abstract}
This research aimed at developing an English Book for economic students based on their needs. The subjects of evaluation were, 2 instructional experts, 2 colleagues, and 30 students for the implementation try out with pre test and post test design. The data was collected using questionnaire and test. The result of evaluation was analyzed through quantitative descriptive technique. The results showed: (1) average test score for draft I by the expert of content was 3,67 and average test score by expert of media was 4,41, the qualification is very good and revision was done (2) average test score for draft II by colleagues was 4,65, the qualification is very good and revision was done, (3) implementation test by the $t$ test towards the result of pretest and post test showed significance score $(0,00)$ is less than 0,05, it means $H_{a}$ is accepted, so it can be said that post test average score is better than pre test average score significantly. It was concluded that the English textbook for economic students that was developed has completed the standard of qualification to be produced and implemented.
\end{abstract}

Keywords: textbook, English, Economic student

\section{PENDAHULUAN}

Dewasa ini bahasa Inggris sudah menjadi kebutuhan bagi siapa saja yang ingin mengembangkan karir ataupun ilmu pengetahuan. Sebagai bahasa asing, Bahasa Inggris wajib dipelajari untuk keperluan pendidikan, bisnis, teknologi, dan lainnya. Terlebih lagi di era MEA (Masyarakat Ekonomi Asean) tentunya juga sangat dibutuhkan kemampuan berbahasa asing, yaitu Bahasa Inggris. Bahasa Inggris telah diajarkan di sekolah dan menjadi mata pelajaran wajib dari tingkat sekolah dasar sampai tingkat perguruan tinggi.

Beberapa perguruan tinggi di Indonesia memasukkan Bahasa Inggris ke dalam kurikulum mereka sebagai mata pelajaran wajib untuk dipelajari. Bahasa Inggris untuk tujuan tertentu mengacu pada pendekatan pembelajaran bahasa yang menuntun peserta didik memenuhi tujuan mengapa mereka perlu mempelajari bahasa target. Pengajaran bahasa Inggris bagi pembelajar yang latar belakangnya bukan bahasa Inggris dikenal dengan English for Specific Purposes (ESP). Menurut Richard (2001: 28), "The concern to make language courses more relevant to learners' needs also led during the period to the emergence of the Languages for Specific Purposes (LSP) movement, known in English language teaching circles as English for Specific Purposes (ESP)."

Efektivitas suatu pembelajaran sangat ditentukan oleh sejauh mana perencanaan yang dilakukan oleh tenaga pengajar. Namun, pengembangan bahan ajar yang dilakukan selama ini baru dalam batas pengadaan bahan cetak berupa hand out, ringkasan materi, dan materi penyajian dalam bentuk Powerpoint. Bahan ajar cetak 
lain seperti buku dan modul masih sangat terbatas dihasilkan. Pengembangan modul hanya sekedar mengumpulkan materi yang langsung diajarkan kepada peserta didik tanpa melakukan analisis kebutuhan dan berbagai proses yang sistemik dan sistematis. Proses penyusunan seperti ini tidak dapat menjangkau kebutuhan peserta didik yang sesungguhnya sehingga materi pembelajaran yang disampaikan cenderung tidak dapat menarik minat peserta didik.

Bahan ajar yang dikembangkan berdasarkan teori desain instruksional memegang peranan penting dalam menciptakan kondisi belajar yang kondusif. Paling tidak terdapat tiga alasan mengapa bahan ajar itu memiliki posisi sentral, yakni (1) sebagai representasi sajian tenaga pengajar, (2) sebagai sarana pencapaian tujuan pembelajaran, dan (3) sebagai pengoptimalan pelayanan terhadap peserta didik. (Zulkarnaini; 2009:5). Pertama, bahan ajar sebagai representasi dari penjelasan tenaga pengajar di depan kelas. Keteranganketerangan, uraian-uraian yang harus disampaikan, dan informasi yang harus disajikan tenaga pengajar dihimpun didalam bahan ajar. Kedua, bahan ajar berkedudukan sebagai alat atau sarana untuk mencapai standar kompetensi dan kompetensi dasar. Ketiga, bahan ajar juga merupakan wujud pelayanan satuan pendidikan terhadap peserta didik. Peserta didik berhadapan dengan bahan yang terdokumentasi dan berhubungan dengan informasi yang konsisten sehingga bagi peserta didik yang cepat belajar, akan dapat mengoptimalkan kemampuannya dengan mempelajari bahan ajar tersebut. Sebaliknya, bagi peserta didik yang lambat belajar, akan dapat mempelajari bahan ajar secara berulangulang. Dengan demikian, optimalisasi pelayanan belajar terhadap peserta didik dapat terselenggara dengan baik melalui penggunaan bahan ajar.

Untuk dapat menghasilkan lulusan yang mampu bertindak sebagai pemakai bahasa Inggris yang baik perlu diupayakan penyelenggaraan pengajaran yang memungkinkan terbentuknya kemampuan berbahasa Inggris sesuai dengan tuntutan pasar kerja. Upaya ini perlu ditempuh secara terusmenerus (intensive) dan berkelanjutan sepanjang masa studi mahasiswa, dengan penciptaan suasana dan bahan ajar yang mendukung serta mendorong penggunaan bahasa Inggris secara aktif. Berdasarkan kebutuhan tersebut dibutuhkan sebuah bahan ajar khususnya bagi pembelajar non Bahasa Inggris. Berdasarkan pada latar belakang masalah dilakukan penelitian pengembangan dengan tujuan menghasilkan buku ajar untuk pembelajaran bahasa Inggris bagi mahasiswa Ekonomi sesuai dengan kebutuhan mereka.

\section{METODE}

Model desain pengembangan yang digunakan dalam penelitian ini adalah model adaptasi langkah-langkah pengembangan dalam Sugiyono (2007). Terdapat 10 langkah pengembangan dalam Sugiyono, yang diadaptasi dalam penelitian ini adalah langkah 1 sampai 6 dan dirangkum menjadi 3 langkah pokok, yaitu:

\section{Kajian Awal}

Pada tahap ini, peneliti mengidentifikasi masalah tentang kebutuhan mahasiswa Ekonomi yang mengambil mata kuliah Bahasa Inggris terkait materi ajar pada mata kuliah tersebut. Peneliti menggali segala yang berhubungan dengan kebutuhan atau permasalahan seperti bahasa apa, makna apa, fungsi-fungsi apa, keterampilanketerampilan berbahasa apa saja yang dibutuhkan.

\section{Desain Produk}

Pada tahap ini, peneliti telah mendesain sebuah materi ajar yang sesuai dengan kebutuhan mahasiswa (Sugiyono, 2007: 298) dengan ber- pedoman pada sejumlah langkah yang disarankan Richards (2001: 264) yang meliputi: (1) Pengembangan tujuan umum, (2) Pengembangan tujuan khusus, (3) Pengembangan silabus, (4) pengorganisasian materi ajar ke dalam unitunit, (5) pengembangan struktur untuk masing-masing unit, dan (6) pengurutan unit.

3. Pengembangan

Tahap ini, terdiri dari: (1) validasi ahli pembelajaran terhadap isi dan desain buku ajar draft I, (2) revisi, menghasilkan buku ajar draft II, (3) validasi teman sejawat terhadap kelayakan bahan ajar draft II, (4) revisi, menghasilkan draft III, (5) uji efektivitas penerapan. Peneliti meminta masukan dari sejumlah pakar dalam bidang bahasa Inggris (expert judgement) tentang materi ajar dikembangkan untuk validasi (Sugiyono, 2007: 298). Dengan kata lain, peneliti mengevaluasi materi ajar 
berdasarkan tujuan yang telah ditetapkan sesuai pendapat pakar (Tomlinson, 1998:97-98).

Yang menjadi subjek uji dalam penelitian pengembangan ini adalah: 2 ahli pembelajaran, 2 teman sejawat dosen, dan 30 mahasiswa untuk uji efektivitas penerapan produk.

Jenis instrument pengumpulan data yang digunakan adalah angket dan tes. Angket adalah sejumlah pertanyaan/ pernyataan yang digunakan untuk memperoleh data baik secara langsung maupun tidak langsung (Usman dan Akbar, 2009: 57). Sedangkan tes adalah sederetan pertanyaan atau latihan yang digunakan untuk mengukur ketrampilan, pengetahuan, intelegensi, dan kemampuan yang dimiliki individu atau kelompok (Hasan, 2014:15). Angket yang digunakan untuk penilaian oleh ahli materi (isi), ahli media, dan teman sejawat dosen berupa angket dengan jawaban tertutup, berisi butir -butir deskripsi komponen penilaian dengan rentang skor "1" hingga " 5 " untuk tiap-tiap butir penilaian, Tes yang digunakan adalah tes tertulis bagi mahasiswa dengan desain pretest dan post-test.

Teknik analisis dalam penelitian ini menggunakan teknik analisis statistik deskriptif. Satistik diskriptif adalah statistic yang digunakan untuk menganalisis data dengan cara mendiskripsikan atau menggambarkan data yang telah terkumpul sebagaimana adanya tanpa bermaksud membuat kesimpulan yang berlaku untuk umum (Sugiyono: 2010:207). Data yang diperoleh melalui angket dari ahli materi dan ahli media, guru dan siswa terhadap produk yang dikembangkan kemudian dianalisis: (1) analisis data untuk hasil angket dilakukan dengan menghitung persentase hasil, yaitu membandingkan jumlah skor hasil penilaian dengan jumlah skor tertinggi kemudian dikonversikan dengan tabel kualifikasi untuk mendapatkan kesimpulan tingkat revisi yang diperlukan terhadap draft pengembangan; (2) analisis terhadap hasil pretest dan posttest dilakukan melalui uji " $\mathrm{t}$ ", dengan hipotesis alternatif $(\mathrm{Ha})$, rata-rata hasil posttest lebih baik dibandingkan rata-rata hasil pretest secara signifikan sesudah penerapan buku ajar yang dikembangkan.

\section{HASIL DAN PEMBAHASAN}

Dalam penelitian ini produk yang dikembangkan berupa Buku Ajar Bahasa Inggris bagi Mahasiswa Ekonomi. Langkah awal yang dilakukan dalam penelitian ini adalah studi pendahuluan yang bertujuan untuk menganalisis kebutuhan mahasiswa. Penelitian dan pengumpulan informasi merupakan langkah awal yang dilakukan dalam proses pengembangan buku ajar ini yaitu dengan cara menyebarkan angket. Berdasarkan hasil angket yang diberikan kepada mahasiswa, tujuan mahasiswa mempelajari bahasa Inggris adalah agar mampu berkomunikasi secara aktif terutama berkaitan dengan hal ekonomi. Hal tersebut terkait kebutuhan dan tujuan mahasiswa dalam mengikuti perkuliahan bahasa Inggris. Selain itu, buku modul/buku pegangan bahasa Inggris sangat diperlukan dalam perkuliahan bahasa Inggris. Buku/ modul yang digunakan saat ini dikemas dalam bahasa Inggris namun berisi General English (Bahasa Inggris secara umum) bukan Bahasa Inggris untuk tujuan tertentu khususnya bidang ekonomi.

Langkah selanjutnya dalam pengembangan buku ajar bahasa Inggris ini adalah desain/ merancang pembuatan buku. Ada beberapa hal yang dilakukan pada tahap ini. Pertama adalah membuat silabus yang berisi tentang standar kompetensi atau tujuan akhir yang ingin dicapai dalam pembelajaran Bahasa Inggris bagi mahasiswa ekonomi. Selanjutnya dilakukan pengumpulan bahan dan referensi melalui buku, modul, dan jurnal terkait materi yang akan dimasukkan ke dalam buku ajar, meliputi: teori, contoh, dan latihan. Ini sejalah dengan apa yang disampaikan oleh Mashura (2003: 351) yang mengatakan bahwa: "bahan ajar harus mampu menarik minat pembelajar dengan cara menyeleksi bahan yang cocok untuk pengajaran."

Setelah menentukan materi yang akan termuat dalam buku ajar, maka selanjutnya dibuatlah kerangka buku ajar. Secara umum buku ajar harus terdiri dari tiga bagian yang mencakup bagian awal, bagian isi, dan bagian akhir (Kurniasih, 2014:71-72). Bagian awal buku ini memuat pendahuluan seperti bahan ajar pada umumnya, yakni halaman cover, halaman judul, kata pengantar, dan daftar isi. Bagian isi terdiri dari delapan materi kegiatan pembelajaran. Dalam masing-masing materi terbagi menjadi beberapa kegiatan yaitu reading (membaca), writing (menulis), speaking (berbicara), dan listening (mendengar) 
yang terintegrasi. Bagian akhir terdiri dari glosarium, daftar pustaka serta sumber artikel dan audio.

Pengembangan berisi beberapa tahap yaitu dilakukan validasi oleh validator ahli materi dan validator ahli desain menggunakan angket. Validator diminta memberikan penilaian berdasarkan butir aspek kelayakan serta memberikan saran dan komentar sebagai bahan revisi. Pada validasi ahli materi, penilaian terbagi menjadi dua aspek kelayakan, yaitu kelayakan isi dan kelayakan penyajian. Hasil penilaian ahli dihitung rata-ratanya dan dikonversikan dengan tabel konversi kualifikasi Hasil validasi ahli materi dapat dilihat pada tabel berikut.

Tabel 1. Ringkasan Hasil Validasi Ahli Materi

\begin{tabular}{|c|l|c|c|}
\hline No & \multicolumn{1}{|c|}{ Aspek } & $\begin{array}{c}\text { Rata- } \\
\text { rata }\end{array}$ & Kategori \\
\hline 1 & Kelayakan Isi & 3,58 & Sangat Baik \\
\hline 2 & $\begin{array}{l}\text { Kelayakan } \\
\text { Penyajian }\end{array}$ & 3,75 & Sangat Baik \\
\hline & Keseluruhan & 3,67 & Sangat Baik \\
\hline
\end{tabular}

Berdasarkan hasil validasi ahli materi (isi), aspek kelayakan isi dan kelayakan penyajian, bahkan secara keseluruhan masuk ke dalam kategori sangat baik.

Pada validasi ahli media, penilaian terbagi menjadi dua aspek kelayakan, yaitu kelayakan kegrafikan dan kelayakan bahasa. Hasil penilaian ahli dihitung juga rata-ratanya dan dikonversikan dengan tabel konversi kualifikasi seperti pada hasil validasi ahli materi. Hasil validasi ahli media dapat dilihat pada tabel berikut.

Tabel 2. Ringkasan Hasil Validasi Ahli Media

\begin{tabular}{|c|l|c|c|}
\hline No & \multicolumn{1}{|c|}{ Aspek } & $\begin{array}{c}\text { Rata- } \\
\text { rata }\end{array}$ & Kategori \\
\hline 1 & $\begin{array}{l}\text { Kelayakan } \\
\text { Kegrafikan }\end{array}$ & 4,39 & Sangat Baik \\
\hline 2 & $\begin{array}{l}\text { Kelayakan } \\
\text { Bahasa }\end{array}$ & 4,44 & Sangat Baik \\
\hline & Keseluruhan & 4,42 & Sangat Baik \\
\hline
\end{tabular}

Berdasarkan hasil validasi ahli materi, semua aspek yaitu kelayakan kegrafikan dan kelayakan bahasa, bahkan secara keseluruhan dinilai sangat baik untuk digunakan.
Walaupun hasil dari kedua validator masuk ke dalam kategori valid dan layak untuk digunakan, buku ajar ini harus tetap melewati proses perbaikan karena masih ada beberapa kesalahan dan kekurangan yang perlu diperbaiki pada tiap bagian buku ajar. Hasil validasi dari kedua ahli menunjukkan bahwa ada beberapa saran perbaikan yang perlu dilakukan peneliti berkenaan dengan buku ajar yang tersebut. Adapun revisi yang perlu dilakukan adalah sebagai berikut:

1. Adanya kesalahan mekanisme penulisan tata bahasa.

2. Belum dicantumkannya sumber setiap teks bacaan yang terdapat dalam buku ajar.

3. Ukuran buku ajar yang kurang sesuai dengan standar.

4. Ukuran huruf sub-topik seharusnya lebih kecil dibandingkan dengan ukuran huruf topik.

5. Perlunya penyesuaian spasi antar alinea teks bacaan yang ada di dalam kotak.

Setelah melewati proses perbaikan, buku ajar ini dilanjutkan ke tahap validasi oleh teman sejawat. Validator diminta memberikan penilaian berdasarkan butir aspek kelayakan serta memberikan saran dan komentar sebagai bahan perbaikan. Pada validasi teman sejawat, penilaian terbagi menjadi empat aspek kelayakan, yaitu kelayakan isi, kelayakan penyajian, kelayakan kegrafikan, dan kelayakan bahasa. Hasil penilaian ahli dihitung juga rataratanya dan dikonversikan dengan tabel konversi kualifikasi seperti pada hasil validasi ahli materi dan ahli media. Hasil validasi teman sejawat dapat dilihat pada tabel berikut.

Tabel 3. Ringkasan Hasil Validasi Teman

\begin{tabular}{|c|l|c|c|}
\hline No & \multicolumn{1}{|c}{ Aspek } & $\begin{array}{c}\text { Rata- } \\
\text { rata }\end{array}$ & Kategori \\
\hline 1 & Kelayakan Isi & 4,64 & Sangat Baik \\
\hline 2 & $\begin{array}{l}\text { Kelayakan } \\
\text { Penyajian }\end{array}$ & 4,57 & Sangat Baik \\
\hline 3 & $\begin{array}{l}\text { Kelayakan } \\
\text { Kegrafikan }\end{array}$ & 4,62 & Sangat Baik \\
\hline 4 & $\begin{array}{l}\text { Kelayakan } \\
\text { Bahasa }\end{array}$ & 4,75 & Sangat Baik \\
\hline & Keseluruhan & 4,65 & Sangat Baik \\
\hline
\end{tabular}

Berdasarkan hasil validasi teman sejawat, semua aspek yaitu kelayakan isi, kelayakan penyajian, kelayakan kegrafikan dan kelayakan 
bahasa, bahkan secara keseluruhan dinilai sangat baik untuk digunakan. Oleh karena itu buku ajar ini dianggap layak dan valid untuk di uji cobakan. Terdapat beberapa saran perbaikan yang diberikan oleh validator teman sejawat berkenaan dengan buku ajar. Adapun revisi yang perlu dilakukan adalah sebagai berikut:

1. Perlu disampaikan tujuan pembelajaran di setiap awal topik.

2. Adanya beberapa kesalahan penulisan dalam beberapa halaman buku ajar

3. Perlunya ditulis semua sumber yang ada termasuk sumber audio listening yang ada di dalam buku ajar.

Setelah melewati proses perbaikan, buku ajar ini dilanjutkan ke tahap uji efektifitas penerapan. Uji efektivitas penerapan dilakukan dengan desain uji pretest dan post-test. Yang menjadi subjek uji dalam hal ini adalah 30 mahasiswa. Uji efektivitas dilakukan melalui penerapan buku ajar untuk satu kompetensi dasar (KD) terhadap keterampilan menulis (writing). Hasil uji coba lapangan dapat dilihat dari hasil postest yang digunakan untuk melihat hasil belajar mahasiswa setelah melakukan pembelajaran menggunakan buku ajar. Berikut ini merupakan deskripsi data hasil belajar mahasiswa:

Tabel 4. Statistik Deskriptif Hasil Belajar Mahasiswa

\begin{tabular}{|c|c|c|c|c|}
\hline & $\overline{\boldsymbol{x}}$ & SD & $\boldsymbol{x} \min$ & $\boldsymbol{x}$ maks \\
\hline Pre test & 61,06 & 7,14 & 46 & 76 \\
\hline Post test & 80,30 & 2,60 & 76 & 84 \\
\hline
\end{tabular}

Sebelum melakukan uji hipotesis dilakukan uji normalitas menggunakan uji statistik Lilliefors pada data hasil belajar mahasiswa dengan bantuan program SPSS 17 for Windows dan didapatkan hasil sebagai berikut

Tabel 5. Ringkasan Hasil Uji Normalitas Tests of Normality

\begin{tabular}{|l|c|c|c|}
\hline \multirow{2}{*}{} & \multicolumn{3}{|c|}{ Kolmogorov-Smirnov ${ }^{\mathrm{a}}$} \\
\cline { 2 - 4 } & Statistic & df & Sig. \\
\hline Pretest &, 091 & 30 &, $200^{*}$ \\
Postest &, 150 & 30 &, 082 \\
\hline
\end{tabular}

*. This is a lower bound of the true significance. a. Lilliefors Significance Correction

Hasil uji normalitas menunjukkan bahwa nilai Sig. pre test dan post test lebih dari
0,05 artinya data hasil belajar mahasiswa berdistribusi normal.

Selanjutnyan pengujian hipotesis menggunakan paired sample $t$ test dapat dilakukan karena data telah memenuhi uji prasyarat kenormalan. Kriteria uji hipotesis dilakukan pada taraf signifikansi 0.05 dengan bantuan program SPSS 17 for Windows. Berikut merupakan rangkuman hasil one sample t test:

Tabel 6. Ringkasan Hasil Uji Hipotesis Paired Samples Test

\begin{tabular}{|c|c|c|c|}
\hline & $\mathrm{t}$ & $\mathrm{df}$ & $\begin{array}{l}\text { Sig. }(2- \\
\text { tailed })\end{array}$ \\
\hline $\begin{array}{ll}\text { Pair } & \text { Pretest - } \\
1 & \text { Postest }\end{array}$ & $-17,665$ & 29 &, 000 \\
\hline
\end{tabular}

Dari hasil paired sample t test di atas, diperoleh nilai Sig. (2-tailed) yaitu $0,00<\alpha(\alpha$ $=0,05)$. Hal ini menunjukkan bahwa $\mathrm{H}_{\mathrm{a}}$ diterima, artinya rata-rata hasil posttest lebih baik dibandingkan rata-rata hasil pretest secara signifikan. Dengan demikian, dapat dikatakan pula bahwa buku ajar Bahasa Inggris berhasil membuat prestasi belajar mahasiswa baik. Karamouzian (2010: 25) yang mengungkapkan bahwa buku teks merupakan titik sentral dalam pembelajaran karena kualitas buku teks dapat berfungsi sebagai faktor penentu tinggi dan rendahnya kualitas pembelajaran bahasa. Belawati (2006) mengatakan bahan ajar berfungsi untuk memotivasi dan membangkitkan seluruh potensi yang dimiliki pembelajar. Bahan ajar sangat penting artinya bagi siswa dan guru dalam pembelajaran.

Berdasarkan hasil-hasil uji pada tiaptiap draft pengembangan telah dilakukan revisi sesuai dengan kualifikasi hasil penilaian dan komentar serta saran oleh masing- masing subjek uji. Berdasarkan hasil pengamatan terhadap uji lapangan telah dilakukan refleksi terhadap kemungkinan perubahan alokasi waktu dan penyederhanaan teks sesuai dengan kemampuan mahasiswa. Revisi menyeluruh terhadap draft pengembangan menghasilkan buku ajar yang dapat dikatakan layak untuk diproduksi dan diterapkan.

\section{PENUTUP}

Ada beberapa kesimpulan yang dapat diambil dari hasil penelitian ini, yaitu: 
1. Setelah melalui tahap analisis kebutuhan dan desain, penelitian ini menghasilkan buku ajar Bahasa Inggris bagi mahasiswa Ekonomi yang terdiri dari berbagai materi dan kegiatankegiatan yang dapat membantu mahasiswa untuk memahami hal-hal yang berkaitan dengan Bahasa Inggris Ekonomi.

2. Hasil validasi dari dua orang validator dan setelah melalui perbaikan, buku ajar Bahasa Inggris bagi Mahasiswa Ekonomi ini telah memenuhi kategori sangat baik dari segi isi (content validity) dan juga konstruksinya (contruct validity). Ini berarti bahwa buku ajar ini layak untuk digunakan.

3. Adanya peningkatan hasil belajar mahasiswa setelah melakukan pembelajaran menggunakan buku ajar Bahasa Inggris bagi mahasiswa Ekonomi.

\section{DAFTAR PUSTAKA}

Belawati, Tian. (2003). Materi Pokok Pengembangan Bahan Ajar Edisi ke Satu. Jakarta: Universitas Terbuka hal 1-3.

Hasan, Iqbal . (2014). Analisis Penelitian Dengan Statistik. Jakarta: PT Bumi Aksara.

Karamouzian, F.M. (2010). A Post-Use Evaluation of Current Reading Comprehension Textbooks Used in TEFL Programs. The Iranian EFL Journal.
December 2010 Volume 6 Issue 4. pp 2462.

Kurniasih, Imas dan Berlin Sani. (2014). Panduan Membuat Bahan Ajar Buku Teks Pelajaran sesuai dengan Kurikulum 2013. Surabaya: Kata Pena.

Mashura, H. (2003). Materials for Developing Reading Skills. In B. Tomlison (Ed). Developing Reading Materials for Language Teaching (pp. 340-363). London: Continuum.

Richards, Jack. C. (2001). Curriculum Development in Language Teaching. Cambridge: Cambridge University Press.

Sugiyono. (2007). Metode Penelitian Kuantitatif, Kualitatif, dan $R$ \& $D$. Bandung: Penerbit Alfabeta.

Sugiyono. (2010). Metode Penelitian Kuantitatif, Kualitatif, dan R \& D. Bandung: Alfabeta.

Tomlinson, Brian. (1998). Materials Development in Language Teaching. Cambridge: Cambridge University Press.

Usman, Husaini \& Akbar, Setiadi Purnomo. (2009). Metodologi Penelitian Sosial. Jakarta: PT Bumi Aksara.

Zulkarnaini. (2009) Pembelajaran dengan Bahan Ajar Buatan Guru diakses dari http://zulkarnainidiran.wordpress.com/20 09/06/28/pembelajaran-dengan-bahanajar-buatan-guru/ 